\title{
An International Relations perspective on the global politics of carbon dioxide capture and storage
}

\author{
Heleen de Coninck ${ }^{\mathrm{a}, *}$, Karin Bäckstrand ${ }^{\mathrm{b}}$ \\ a Energy Research Centre of the Netherlands, Unit Policy Studies, Radarweg 60, 1043 NT Amsterdam, Netherlands \\ ${ }^{\mathrm{b}}$ Department of Political Science, Lund University, P.O. Box 52, 22100 Lund, Sweden
}

A R T I C L E I N F O

\section{Article history:}

Received 1 June 2010

Received in revised form 19 March 2011

Accepted 20 March 2011

\section{Keywords:}

Carbon dioxide capture and storage (CCS)

International organisations

International Relations

Climate governance

Energy

Fossil fuels

\begin{abstract}
A B S T R A C T
With the publication of the IPCC Special Report on Carbon dioxide Capture and Storage (CCS), CCS has emerged as a focal issue in international climate diplomacy and energy collaboration. This paper has two goals. The first goal is to map CCS activities in and among various types of intergovernmental organisations; the second goal is to apply International Relations (IR) theories to explain the growing diversity, overlap and fragmentation of international organisations dealing with CCS. Which international organisations embrace CCS, and which refrain from discussing it at all? What role do these institutions play in bringing CCS forward? Why is international collaboration on CCS so fragmented and weak? We utilise realism, liberal institutionalism and constructivism to provide three different interpretations of the complex global landscape of CCS governance in the context of the similarly complicated architecture of global climate policy. A realist account of CCS's fragmented international politics is power driven. International fossil fuel and energy organisations, dominated by major emitter states, take an active role in CCS. An interest-based approach, such as liberal institutionalism, claims that CCS is part of a "regime complex" rather than an integrated, hierarchical, comprehensive and international regime. Such a regime complex is exemplified by the plethora of international organisations with a role in CCS. Finally, constructivism moves beyond material and interest-based interpretations of the evolution of the institutionally fragmented architecture of global CCS governance. The 2005 IPCC Special Report on CCS demonstrates the pivotal role that ideas, norms and scientific knowledge have played in transforming the preferences of the international climate-change policy community.
\end{abstract}

(c) 2011 Elsevier Ltd. All rights reserved.

\section{Introduction}

Climate change is generally acknowledged as a human-induced, global issue (IPCC, 2007a). There is widespread recognition that addressing climate change will require the full portfolio of mitigation options (IPCC, 2007b; IEA, 2008a). Such technologies include end-use energy efficiency, fuel switching, renewable energy and carbon dioxide capture and storage (CCS). As the most recent addition to the climate change mitigation portfolio, CCS has become a heated topic in global climate politics. CCS has emerged as a negotiation item in international climate diplomacy, and the number of intergovernmental organisations working on CCS has grown rapidly over the past few years (Coninck et al., 2009).

Despite CCS's heightened priority on the global political agenda, the institutional fragmentation of international organisations and multilateral institutions dealing with CCS is evident. This

\footnotetext{
* Corresponding author. Tel.: +31224 564316; fax: +31 224568339

E-mail addresses: deconinck@ecn.nl (H. de Coninck),

Karin.backstrand@svet.lu.se (K. Bäckstrand).
}

fragmentation is symptomatic of weak global governance arrangements around energy technologies, coupled with the absence of energy issues from the UN's policy agenda (Karlsson-Vinkhuyzen, 2010). This institutional fragmentation is also evident in global climate policy, where the prospects for a comprehensive, universal, legally binding international agreement are low after the Copenhagen climate summit in December 2009. Such concepts as "a building block approach" (Falkner et al., 2010) and a "climate regime complex" (Keohane and Victor, 2010), terms signifying an increase in institutional fragmentation and diversity, have replaced the concept of a universally negotiated, global climate agreement.

Against the background of CCS as a likely necessary mitigation option and the potential development of international agreements, it is of interest to study the international politics of CCS. This paper engages in such study in two ways: first, by mapping CCS collaboration in various types of intergovernmental organisations and second, by applying International Relations (IR) theories to explain the growing diversity, overlap and fragmentation of international organisations dealing with CCS. Despite the growing number of international organisations active in the field of CCS, IR

0959-3780/\$ - see front matter (c) 2011 Elsevier Ltd. All rights reserved. doi:10.1016/j.gloenvcha.2011.03.006 
scholars have so far written little about the global governance of CCS. This paper advances realism, liberal institutionalism and constructivism as three different interpretations of the complex global landscape of CCS governance and the equally complicated climate policy architecture at large (Biermann et al., 2009; Aldy and Stavins, 2010).

The first set of questions in this paper relates to how organisations treat CCS. Which type of international organisations embraces CCS, and which refrains from discussing it at all? What governance functions (information sharing, capacity building, standard setting, etc.) do different organisations perform with respect to CCS? Are the organisations positive, negative or neutral with respect to CCS technologies? A second set of questions revolves around why. Why is the international collaboration on CCS so fragmented, and why are soft governance functions, such as information sharing, predominant? Why do some organisations appear much less interested in CCS than others?

The remainder of this section briefly traces the history of CCS in global politics. The second section summarises the debate in the IR literature among power-based (realist), interest-based (liberal institutionalist) and knowledge-based (constructivist) arguments over the relevance of international institutions and outlines methods for interpreting the diversity of CCS-related international organisations. The third section categorises various types of international organisations active in the field of CCS, identifies their positions on CCS and summarises their governance functions. In the fourth section, we apply realist, liberal-institutionalist and constructivist approaches to analyse the fragmented global institutional response to CCS. We discuss the results of our study and their implications for future research in the concluding section.

Meadowcroft and Langhelle (2009a,b) provide a history of CCS in the realms of international cooperation and global climate and energy politics. Marchetti (1977) first proposed CCS; thereafter, throughout the 1990s, a number of countries expressed interest in the concept. CCS finally made an appearance on the international policy agenda after the publication of the Intergovernmental Panel on Climate Change Special Report on CCS (2005). The IPCC Special Report reviewed the technology's maturity, costs, environmental impacts, risks and legal and regulatory issues. However, that report was limited by its mandate to be neutral with regard to policy prescriptions; its authors refrained from identifying these issues as barriers to CCS deployment. Since 2005, the International Energy Agency (IEA) has been the main provider of information on economic and regulatory developments in the CCS field. Optimism regarding CCS technology on the part of industry, governments and academics contrasts with studies that highlight unresolved barriers to CCS (Shackley et al., 2008; Coninck et al., 2008; IEA, 2009; Meadowcroft and Langhelle, 2009a,b).

Over the past five years, CCS has become a prominent item on the agendas of multilateral institutions and international organisations, as well as in global energy and climate diplomacy. The G8, during its CCS Gleneagles meeting in 2008, set a target of 20 fullscale CCS demonstration plants by 2010 . While member countries did not meet this target, several governments (Canada, Australia and the United States) and the European Union (EU) have set domestic CCS demonstration targets and secured considerable funds. CCS has also emerged as a contested issue in international climate negotiations. In the United Nations Framework Convention on Climate Change (UNFCCC), CCS was debated for five years as a potential technology under the Clean Development Mechanism (CDM), until the issue was resolved in principle in December 2010. International organisations concerned with energy issues and fossil fuel production, such as the IEA, the Organization of Petroleum Exporting Countries (OPEC) and the International Energy Forum (IEF), have also prioritised CCS on the their agendas.
In addition, governments have initiated relevant ministerial forums, such as the Carbon Sequestration Leadership Forum (2003). The Global CCS Institute's establishment in 2009 represents the recent rise of international organisations outside the ambit of the UN. Yet, despite the initiation of CCS-related activities among numerous international organisations, key multilateral agencies do not explicitly consider the technology. Neither the United Nations Environment Programme (UNEP) nor the UN Energy and the Commission on Sustainable Development (CSD) have added CCS to their agendas.

\section{Do international institutions matter? Realism, liberal institutionalism and constructivism}

A key issue in IR research revolves around explaining and interpreting the emergence and effects of international organisations and international collaboration in a world constituted by sovereign, territorially organised states. Three strands of IR theory - realism, liberal institutionalism and constructivism - provide different answers to the question of the relevance of international institutions and regimes in the transformation of state preferences and behaviour (Vogler, 2010). Alternatively, we can frame these perspectives as power-based, interest-based and knowledgebased explanations for how international organisations evolve in various policy domains. In the study of international environmental politics, liberal institutionalism represents the predominant theoretical approach to explaining the dramatic increase in multilateral organisations and global governance arrangements that has taken place since the 1960s. Moreover, constructivist approaches, represented by the "epistemic community" concept, which highlights the role of scientific knowledge and transnational networks of scientists in propelling international environmental cooperation, have also gained ground. However, after the 2009 UN Climate summit in Copenhagen failed, realist thinking in global climate politics revived (Bernstein et al., 2010). This line of work argues that the weakening of multilateral climate diplomacy has led to the rise of a new geopolitics of climate change. The locus of power has shifted from UN institutions to new alliances among major industrialised and developing emitter states.

According to power-based traditions such as realism, material interests and state power are the main explanations behind the establishment of international organisations in an anarchical world. Realism defines anarchy in this context as the absence of a central authority above the state. In hegemonic stability theory, a hegemon such as the US is a key actor in promoting international regimes that protect its interest in maintaining a stable world order. The crucial role the US played in establishing multilateral economic institutions, such as the World Bank and International Monitory Fund (IMF) in 1946, exemplifies how hegemonic interests shaped the global economic order after World War II (Falkner, 2005). International collaboration on such issues as CCS, biodiversity, poverty and terrorism reflect major states' national interests in promoting shared problem solving in an international regime. In realism, the hegemon's motivation and the distribution of power capabilities are more important factors in explaining the characteristics of international institutions than is institutional design. A hegemon can also withdraw support from an international regime if it perceives that the regime is inimical to its national interests. The US withdrawal from the Kyoto Protocol in 2001 is emblematic of a unilateral impulse and the dynamics of realpolitik. However, perceptions of the national interest can change when power changes. In a realist reading, the rapprochement between Obama and the international climate regime, represented by the 2009 Copenhagen Accord, paved the way for a new geopolitical world order, wherein the US, China and other major emitters set the agenda. Accordingly, international organi- 
sations and intergovernmental treaty making are only epiphenomenal to the power and interests of states and are subordinated to sovereignty. States can pool sovereignty in the name of joint problem solving without infringing on their national sovereignty. Realist theory would predict that states with fossil-fuel dependent energy systems would be key actors in establishing international organisations and denser systems of intergovernmental cooperation on CCS because CCS represents a transitional technology in a carbon-constrained world.

In contrast, such interest-based accounts as liberal institutionalism contend that there is a functional need for international regimes in a world characterised by collective action problems. Climate change represents the ultimate global tragedy of the commons. Liberal institutionalism emphasises the demand for international organisations as an arena of joint problem solving (Keohane, 1984). Essentially, the demand for international organisations comes from states wishing to resolve collective action problems by providing public goods (Bodansky, 2010). Even powerful governments that could resolve certain problems alone seek international collaboration for reasons of efficiency (reducing transaction costs) and legitimacy (Abbott and Snidal, 1998). If a permanent institution can provide such solutions more easily, demand for an international institution or regime arises (Bodansky, 2010). Regimes are understood as a "set of implicit and explicit principles, norms, rules, decisionmaking procedures around which actor expectations converge in a given issue area" (Krasner, 1983, pp. 3-4). Regimes provide a stable institutionalised setting - "cooperation under anarchy" where states can coordinate their behaviour by shaping joint global institutions (Keohane, 1984). From the perspective of regime theory, the plethora of international institutions on CCS in energy and climate change policy domains reflects a need among states to establish rules and regulations in areas that lie beyond their national jurisdictions. However, scholars have criticised the regime approach for its state-centric methodology. Consequently, pluralist methodologies, exemplified by notions of "global governance" that recognise a complex web of private and public actors beyond the nation-state, have come to supplement the regime approach (Biermann, 2006; Young, 1997). Governance of CCS issues takes place in overlapping "spheres of authority" encompassing informal networks of governments, intergovernmental organisations, NGOs and business (Rosenau, 2007). The literature on transnational governance examines the role of non-state actors, such civil society and business, within international regimes and interstate bargaining processes (Ford, 2010).

We also find a strand of liberal institutionalism in recent work on the concept of "regime complex". The core argument of this approach holds that there is no integrated, hierarchical and comprehensive regulatory regime for climate change but rather a loose set of coupled regimes and institutional efforts that exist as regime complexes (Keohane and Victor, 2010). The UN legal regime (UNFCCC) is one node in a fragmented climate-change regime complex. This regime complex consists of more narrow regimes, such as scientific assessment institutions (IPCC), bilateral initiatives, "carbon clubs" or coalitions of willing states (Major Emitters Forum, G20), specialised UN agencies, public-private partnerships, and so on. The CCS-related international organisations represent a cluster of evolving institutions centred on global technology cooperation in a climate-change regime complex. The difference between the climate regime and the CCS regime is that the former regulates an issue area while the latter concentrates on technological advancement. Liberal institutionalist theories that employ the concept of regime complex conceive of international organisations concerned with CCS as part of a narrow regime, defined primarily by states and private actors, which benefits from the deployment of CCS technology due to externally imposed efforts to curb greenhouse gas emissions.

While research on global governance and regime complexes opens the way for an analysis of non-state actors, realism and liberal institutionalism largely share an emphasis on inter-state cooperation and on the positivistic assumptions of a rational-actor model that treats state interests and motivations as given and fixed. In contrast, constructivism stresses the evolution of norms, discourses, identity, knowledge and values. It also emphasises the role non-state actors, such as scientists and civil society, play in influencing the evolution of international environmental cooperation. International norms, defined as shared conceptions of appropriate behaviour, shape international cooperation (Finnemore and Sikkink, 1998), and "norm entrepreneurs" can transform the interests of governments. Knowledge-based approaches claim that the evolution of international regimes, treaties and organisations can be explained not only by power capabilities or state interests but also by normative and discursive shifts, where scientific knowledge plays a pivotal role in framing uncertainty and presenting new scientific evidence for policymakers. Transnational networks of scientists in epistemic communities "are both politically empowered through their claims to exercise authoritative knowledge and motivated by shared causal and principled beliefs" (Haas, 1990, p. 349). Constructivists can conceive the IPCC as an epistemic community that shares understandings of the causal processes and impacts of climate change, normative beliefs and a common policy enterprise (i.e., to combat anthropocentric climate change) (Bulkeley and Newell, 2010, p. 8). Litfin's (1992) work on how a precautionary discourse advanced by scientists, or "knowledge brokers", gained ground during the negotiations over the Montreal Protocol on the stratospheric ozone layer is another constructivist account of how knowledge conditions policy. Constructivism argues that the discursive rapprochement between the climate change and the energy and fossil-fuel communities, represented by the 2005 publication of the IPCC Special Report on CCS, illustrates the importance of scientific knowledge in shaping the preferences of states, international organisations and industry actors associated with oil and gas interests (Meadowcroft and Langhelle, 2009a,b, p. 267).

\section{Mapping CCS international organisations}

Keohane (1988, p. 380) argues that "all efforts of international collaboration take place within an institutional context of some kind". Collaboration can range from strongly institutionalised cooperation, which involves a charter, secretariat, funding and staff, to less institutionalised organisations with partial memberships, such as networks or high-level policy forums, like the G8 or G20. Existing international organisations have taken up CCS; new international institutions have also arisen that focus exclusively on the advancement of CCS.

This section maps and categorises those international organisations that currently have CCS on their agendas. We identify three types of organisations: scientific organisations, UN and multilateral organisations and fossil fuel- or energy-driven international organisations or networks outside the UN family. Our aim is to identify these organisations' primary goals with regard to CCS technologies, their position on CCS (positive, neutral or negative) and their level of activity in the CCS field. Finally, we analyse their governance functions.

\subsection{Scientific international organisations: Intergovernmental Panel on Climate Change}

In 2001, the UNFCCC, through its Subsidiary Body on Scientific and Technological Advice (SBSTA), requested that the IPCC assess 
the scientific, technological and socio-economic aspects of CCS. The IPCC is an intergovernmental organisation hosted by UNEP and the World Meteorological Organisation (WMO) that provides scientific and technological assessment. We can conceptualise the IPCC as an epistemic community because it represents a large, transnational network of scientists who are nominated by their national governments to participate in an IPCC report-writing effort (Bulkeley and Newell, 2010). The IPCC provides scientific assessment to policy makers and negotiators. It is governed by an IPCC Plenary, which consists of its 188 member states. Nominated scientists and experts, mostly from independent institutions such as universities, write the assessments. The assessment work is organised in three working groups: Working Group I on the science of climate change, Working Group II on impacts and adaptation and Working Group III on mitigation.

The SBSTA request to the CCS was made to Working Group III on mitigation. The IPCC Plenary meeting decided first to hold a scoping meeting on the topic in 2002. This meeting resulted in a decision by the IPCC Plenary to commission a Special Report on CCS. This report was approved and published in late 2005. We can view this report as the first capacity-building effort on CCS because its authorship group contained many researchers from developing countries. These researchers benefited from their involvement in the writing of the report and their participation in the Lead Author meetings.

Another IPCC activity, which began in parallel with the writing of the Special Report, was the 2006 revision of the Guidelines for National Greenhouse Gas Inventories. An IPCC Task Force undertook this project. Consistency between the two products was achieved by an overlap of authors. Although they did not attract the same level of attention as the IPCC Special Report, the fact that the new Inventory Guidelines acknowledged CCS was a significant step. However, due to broader negotiation issues, the Parties of the UNFCCC have not yet accepted the 2006 Guidelines. Therefore, no official method exists for countries taking account of CCS in their national greenhouse gas inventories for demonstrating compliance with their Kyoto commitments.

\subsection{International climate diplomacy and multilateral organisations}

CCS has also entered the agenda of international climate diplomacy as a separate subject of negotiation. The United Nations Framework Convention on Climate Change (UNFCCC) aims at "preventing dangerous anthropogenic interference with the climate system" (Article 2 of the UNFCCC). In December 2005 at COP11 in Montreal, the UNFCCC, through SBSTA, welcomed the IPCC Special Report on CCS, thereby acknowledging CCS as a legitimate mitigation option.

Earlier that year, Japanese project developers submitted two new methodologies for two CCS projects associated with the Kyoto Protocol Clean Development Mechanism (CDM) in time for consideration at the CDM Executive Board's meeting that immediately preceded COP11. The CDM EB requested more guidance on CCS in the CDM from the COP/MOP. COP/MOP decided it needed more information on how CCS functions in the CDM. The UNFCCC's Subsidiary Body on Scientific and Technical Assistance organised two in-session workshops in 2006 in Bonn. These meetings, although clarifying countries' positions, did not lead to conclusions on CCS in the CDM for over four years. However, during COP16 in December 2010, CCS was deemed eligible as a CDM project activity, contingent upon the fulfilment of a number of conditions and procedural requirements (UNFCCC, 2010).

Outside the UN family, the World Bank organised a workshop on CCS capacity building in 2009 in Washington, DC. This workshop brought together various actors in the field of CCS capacity building, including such international organisations as the
Global CCS Institute (GCCSI) and the IEA, the governments of Japan and Norway and private actors, such as Shell and the Energy research Centre of the Netherlands (ECN). The Global Environment Facility (GEF) considered CCS in 2007 but did follow up; the only project GEF is now funding is a demonstration of CCS bio-fuel production in Brazil.

The UN Industrial Development Organization (UNIDO) is the most recent organisation to become active in CCS activities. Jointly with the IEA and with funding from Norway and the GCCSI, UNIDO is developing a Roadmap on CCS for industrial sectors, which will be published in 2011. UNIDO also made sure CCS was included in the recommendations that the UN Advisory Group on Energy and Climate Change issued in 2010 (AGECC, 2010). However, other UN organisations, such as the United Nations Development Programme (UNDP) and the United Nations Environment Programme (UNEP), have not undertaken specific CCS work.

\subsection{Fossil fuel or energy-driven international organisations}

Several international organisations, public-private partnerships and forums outside the UN family have taken up CCS. The US and other large fossil fuel economies are influential members or initiators of these organisations. We can conceptualise them as "clubs" of like-minded countries involved in the deployment of CCS technologies (Keohane and Victor, 2010). The International Energy Agency (IEA), set up in 1974 by western oil-consuming countries as a response to an OPEC oil embargo, is the pioneering international organisation in the field of CCS. IEA, which consists of the OECD countries, has transformed itself from an emergency organisation contending with an oil crisis to a global energy advisor on the subjects of climate mitigation and sustainability (Graaf and Lesage, 2009). It has more than forty so-called "implementing agreements". Among these agreements is the IEA Greenhouse Gas R\&D Programme (IEA GHG), which is the first international organisation to focus on CCS and has been in place since 1991. Operating independently of the IEA proper, the IEA GHG organised, in the early 1990s, the first international conference on CCS, the International GHG Technologies Conference. IEA GHG has continued to commission technical studies in the field of CCS and since 2007 organises an annual Summer School. Moreover, its roughly biannual conferences attract increasing numbers of participants. The IEA GHG is managed by its members, a combination of governments and industry. For its Special Report, the IPCC drew heavily on both the studies commissioned by the IEA GHG, and its employees: most of the IEA GHG employees were authors (IPCC, 2005; Meadowcroft and Langhelle, 2009a,b). The Clean Coal Centre is the product of another IEA implementing agreement. This Centre focuses more on clean coal technologies without CCS.

From about 2003 onwards, the IEA itself began work on CCS. Since 2004, it has published books on modelling studies and basic data on CCS (IEA, 2004, 2008b). Since 2006, CCS has appeared in key IEA products, such as the World Energy Outlooks. CCS was one of the first technologies for which the IEA provided a Global Technology Roadmap (IEA, 2009). Such roadmaps consist of a combination of long-term scenarios, actions and milestones for various actors in their attempts to develop and deploy a particular technology.

In 2003, the United States took the initiative in simultaneously establishing two technology-oriented agreements: the International Platform on the Hydrogen Economy and the Carbon Sequestration Leadership Forum (CSLF). CSLF focuses on CCS. ${ }^{1}$

\footnotetext{
${ }^{1}$ In the United States, the term "carbon sequestration" or "carbon capture and sequestration" is often used instead of the internationally more common term "carbon capture and storage". Another term, "geosequestration", is more common in Australia.
} 
Table 1

Relevant organisations, their core topic area, primary aim and position and level of activity in relation to CCS.

\begin{tabular}{|c|c|c|c|}
\hline Organisation name & Topic area & Primary aim & CCS position \\
\hline \multicolumn{4}{|l|}{ Science-oriented organisations } \\
\hline $\begin{array}{l}\text { Intergovernmental Panel on } \\
\text { Climate Change (IPCC) }\end{array}$ & Climate change & $\begin{array}{l}\text { Assess scientific and technical } \\
\text { information related to climate change }\end{array}$ & $\begin{array}{l}\text { Neutral. Considers CCS a mitigation } \\
\text { technology but does not advocate CCS }\end{array}$ \\
\hline \multicolumn{4}{|c|}{ Multilateral organisations (UN and Bretton Woods) } \\
\hline $\begin{array}{l}\text { United Nations Environment } \\
\text { Programme (UNEP) }\end{array}$ & Environment & Improve the environment globally & $\begin{array}{l}\text { CCS is not considered. Focus is on } \\
\text { energy efficiency and renewable energy }\end{array}$ \\
\hline $\begin{array}{l}\text { United Nations Development } \\
\text { Programme (UNDP) }\end{array}$ & Development & Help people build a better life & Not considered \\
\hline $\begin{array}{l}\text { United Nations Framework } \\
\text { Convention on Climate } \\
\text { Change (UNFCCC) }\end{array}$ & Climate change & $\begin{array}{l}\text { Prevent dangerous human interference } \\
\text { with the climate system }\end{array}$ & $\begin{array}{l}\text { Neutral. Considers CCS a mitigation } \\
\text { technology but does not advocate CCS }\end{array}$ \\
\hline World Bank & Development & $\begin{array}{l}\text { Fight poverty through financing for } \\
\text { economic development }\end{array}$ & $\begin{array}{l}\text { Neutral. On-demand funding of } \\
\text { feasibility studies or capacity building }\end{array}$ \\
\hline $\begin{array}{l}\text { Global Environment Facility } \\
\quad(\text { GEF })\end{array}$ & Environment & $\begin{array}{l}\text { Promote environmentally friendly } \\
\text { technologies in developing countries }\end{array}$ & $\begin{array}{l}\text { Not considered. No funding for CCS } \\
\text { projects. Focus is on energy efficiency } \\
\text { and renewable energy }\end{array}$ \\
\hline $\begin{array}{l}\text { United Nations Industrial } \\
\text { Development Organisation } \\
\text { (UNIDO) }\end{array}$ & Development & $\begin{array}{l}\text { Promote sustainable industrial } \\
\text { development }\end{array}$ & $\begin{array}{l}\text { Neutral. Facilitates but does not } \\
\text { advocate, CCS }\end{array}$ \\
\hline \multicolumn{4}{|c|}{ Fossil fuel- or energy-driven international organisations } \\
\hline $\begin{array}{l}\text { Carbon Sequestration } \\
\text { Leadership Forum (CSLF) }\end{array}$ & CCS & Enable CCS through dialogue and study & Positive. Actively advocates CCS \\
\hline $\begin{array}{l}\text { International Energy Forum } \\
\text { (IEF) }\end{array}$ & $\begin{array}{l}\text { Fossil fuels/ } \\
\text { energy }\end{array}$ & $\begin{array}{l}\text { Align interests of energy importers and } \\
\text { energy exporters through dialogue }\end{array}$ & Positive. Actively advocates CCS \\
\hline $\begin{array}{l}\text { International Energy Agency } \\
\text { (IEA) }\end{array}$ & $\begin{array}{l}\text { Energy with a } \\
\text { slight fossil fuel } \\
\text { orientation }\end{array}$ & $\begin{array}{l}\text { Improve energy security for OECD } \\
\text { countries; represents interests of } \\
\text { energy importers. }\end{array}$ & $\begin{array}{l}\text { Positive. Facilitates CCS through } \\
\text { independent studies }\end{array}$ \\
\hline $\begin{array}{l}\text { Organisation of Petroleum } \\
\text { Exporting Countries (OPEC) }\end{array}$ & Fossil fuel & Represent interests of energy exporters & $\begin{array}{l}\text { Positive. Currently does not politically } \\
\text { advocate CSS }\end{array}$ \\
\hline Global CCS Institute (GCCSI) & CCS & Facilitate demonstration of CCS projects & Positive. Actively advocates CCS \\
\hline
\end{tabular}

Source: Organisations' websites or public statements.

We can conceptualise these agreements as technology partnerships between governments and industry, or as trans-governmental networks (Bäckstrand, 2008; Slaughter, 2004). Approximately 500 representatives from governments, industry and research actors attended the inaugural meeting. A majority of the invited countries were reliant on fossil fuels, particularly as exporters, including Saudi Arabia, China, South Africa, Australia, Norway and Canada. Noteworthy from a political viewpoint was that another apparent invitation criterion was an alliance with the United States in general geopolitical affairs. This criterion could explain why Colombia was invited (an ally of the US administration in the war on drugs but insignificant on CCS). Italy and the UK, which at the time were faithful allies in the war on terrorism in Afghanistan and Iraq, were the only European Union member states invited.

The 2003 inaugural meeting agreed on a charter that established the CSLF as a knowledge-sharing platform. Several more countries subscribed to the charter, bringing the total to 22 countries in 2010. CSLF's outputs include work on methodologies for storage potential, as well as the organisation of capacity-building activities when developing country members have hosted its annual meetings. Interestingly, CSLF does not refer of the Kyoto Protocol (which the United States had rejected just two years previously) despite the obvious connection between CCS and climate change and the fact that most CSLF member countries are parties to the Kyoto Protocol.

The Organisation of Petroleum-Exporting Countries (OPEC) has cooperated with the IEA GHG to organise expert workshops on CCS and the CDM. The aim was to help including CCS in the CDM, which would give OPEC member countries access to carbon finance. OPEC has also arranged workshops for professionals from member countries in collaboration with the IEA GHG.

Australian Prime Minister Kevin Rudd announced the establishment of the Global CCS Institute (GCCSI) in 2008. GCCSI was founded in 2009 with the aim of facilitating the demonstration and commercialisation of CCS. GCCSI is a non-governmental organisation with headquarters in Canberra and hubs on other continents. With a substantial budget of 100 million Australian dollars per year (until 2013), it has, so far, primarily funded large, informationcollection consultancy studies, other organisations' work on CCS (including work that IEA and the IEA GHG have performed), research into public perception and engagement, and collaborations on capacity building with other public and private stakeholders. GCCSI adopted a capacity-development strategy in 2010, with a focus on six developing countries: China, India, Indonesia, Mexico, Malaysia and South Africa. Although, the new Australian Labour government cut GCCSI's budget significantly after Rudd left office, the GCCSI is still one of the resourceful international organisations active in CCS.

The International Energy Forum (IEF) is an international organisation located in Saudi Arabia. The IEF attempts to bring together the interests of fossil fuel-exporting and importing countries. Jointly with the GCCSI, the IEF organised a series of workshops on CCS in 2009 and 2010 in Beijing and Algiers. The Beijing workshop resulted in a statement highlighting the importance of enhanced oil recovery (EOR).

\subsection{CCS positions and aims of international organisations active in CCS}

We should view the positions (positive, negative or neutral) on CCS technologies that different types of international organisations have adopted within the context of each organisation's central mission, core aim and topical focus. Table 1 categorises international organisations according to their topic area, including development, environment, climate change, CCS and fossil fuels. The relationship between the topic of CCS and that of climate change is the strongest because the sole purpose of the vast majority of CCS applications is climate change mitigation. ${ }^{2}$ Indeed, all other relations with CCS are necessarily contingent on climate

\footnotetext{
${ }^{2}$ There are a few exceptions. In $\mathrm{CO}_{2}$-enhanced oil, gas or coal bed methane recovery, the purpose can be additional hydrocarbon recovery. In addition, there are projects that inject a mixture of $\mathrm{H}_{2} \mathrm{~S}$ and $\mathrm{CO}_{2}$ (acid gas) underground to prevent the release of acid gas into the environment.
} 


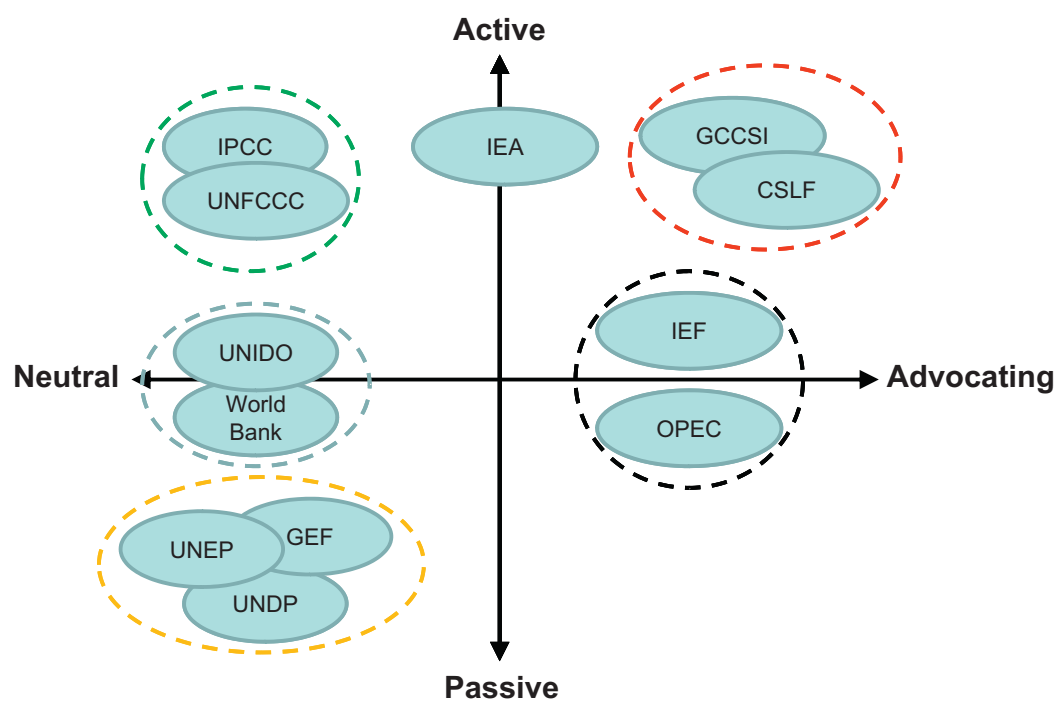

Fig. 1. Illustration of the positions and level of activity of relevant international institutions with regard to CCS. For an explanation of the acronyms, see Table 1.

change mitigation. As CCS would be applied as a mitigation option in industry and energy sectors, the relationships between CCS and the energy and industrial sectors are critical. Because climate change mitigation and adaptation directly affect development, an indirect relation exists between CCS and development, although no such relationship exists between CCS and poverty alleviation agendas, such as the UN Millennium Development Goals. Some organisations frame CCS differently. The technology allows for economic development and industrialisation based on affordable fossil fuels while limiting greenhouse gas emissions; therefore, international organisations focusing on fossil fuels are likely to have CCS in their portfolio. If climate change mitigation were to be enforced in the future, CCS is the only abatement option that would allow the industrial and energy sectors to continue using fossil fuels.

Table 1 gives an overview of international organisations that are potentially relevant for CCS, their core topic, primary aim and their stated position on CCS.

Table 1 allows for some general observations on the linkage between an international organisation's position on CCS and its primary aim. First, member-driven fossil fuel international organisations that have CCS as their core mission, such as CSLF and GCCSI, invariably take a positive stance on CCS. A link exists between an orientation towards fossil fuels and advocacy of CCS technologies. This finding is not surprising; the membership of such organisations is composed of fossil-fuel dependent states in the developed and developing worlds. However, the fact that their members are dependent on fossil fuels may undermine the credibility of these organisations in their claims to provide neutral and independent information on CCS.

Multilateral organisations may be better suited to the task of providing independent information. Such organisations are active in the field of CCS but also take a neutral stance and do not prefer CCS to other mitigation options. However, only few multilateral organisations are active in CCS. The World Bank and UNIDO, both of which have a strong development focus, have undertaken initiatives in CCS. The World Bank, funded by Norway, set up a capacity-development programme. UNIDO, sponsored by Norway and the GCCSI and in collaboration with the IEA, is developing a global technology roadmap for CCS in industry. While the core mission of these organisations is development, concern for climate change, combined with the influence of CCS-oriented governments and other organisations, has led them to undertake actions in the CCS field.
Finally, UN organisations in the environmental and development fields are neither active nor take a position on CCS. Many of these organisations promote other energy technologies, particularly energy efficiency and renewable energy.

Another general observation is the level of coordination that exists among the fossil-fuel oriented international organisations. For example, the IEA GHG works with OPEC in organising joint workshops on CCS. The IEA and CSLF collaborated on making recommendations for near-term opportunities in CCS for the benefit of the G8. Since its formation in a fragmented landscape of international organisations already active in CCS, the GCCSI has attempted to form strategic alliances with existing institutions. As a well-funded but newly established organisation, the GCCSI has allocated significant resources to developing a CCS unit at the IEA and its IEA GHG. GCCSI also funds an activity within UNIDO and collaborates with the IEF on CCS workshops in developing countries. The fragmentation in the CCS field is countered by collaboration between international organisations.

The positions of the groupings of international organisations are graphically illustrated in Fig. 1.

Fig. 2 summarises the most important events over time, which highlights the role of different international organisations in CCS activities between 1990 and 2010. The pioneering international organisation with the earliest engagement from 1990 onwards is IEA GHG, followed by the IEA and the IPCC. IEA took up CCS early in this period with the explicit aim of promoting CCS deployment. As we previously noted, the IPCC rated CCS as a climate mitigation option in its Special Report from the early 1990s. After the report, CCS was included as a UNFCCC negotiation topic under the Clean Development Mechanism.

\subsection{Governance functions of CCS-related international organisations}

Table 2 summarises the various functions that international organisations perform in the CCS field. Soft governance functions, such as information sharing and capacity building, dominate these activities, an issue to which we will return in the next section. Abbott and Snidal (1998) analyse governance functions of formal international organisations in terms of centralisation and independence. Common functions under these broader categories include support for state and non-state interactions, management of substantive operations, procedures for elaborating norms, "laundering" (i.e., channelling money or resources through an independent organisation to "neutralise" it from national flavour) 


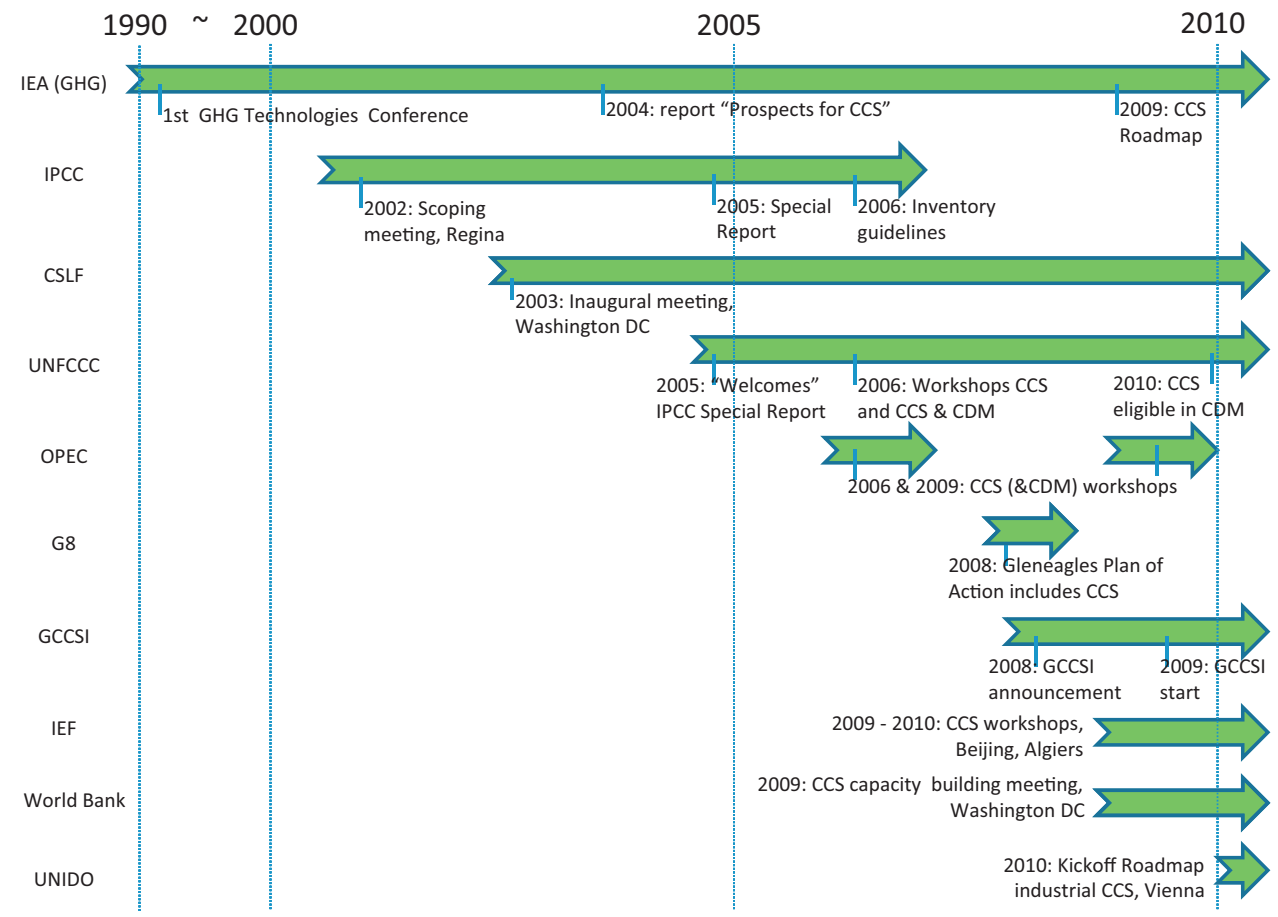

Fig. 2. Timeline and milestones of international organisations in the field of CCS.

Table 2

Governance functions of CCS-related international organisations.

\begin{tabular}{|c|c|c|c|c|c|c|}
\hline & $\begin{array}{l}\text { Information } \\
\text { sharing }\end{array}$ & $\begin{array}{l}\text { Awareness and } \\
\text { capacity developing } \\
\text { countries }\end{array}$ & $\begin{array}{l}\text { Information provision, } \\
\text { joint } R \& D \text { and studies }\end{array}$ & $\begin{array}{l}\text { Regulatory } \\
\text { development }\end{array}$ & Feasibility studies & Project financing \\
\hline CSLF & Meetings & Workshops & & & & \\
\hline IEF & Workshops & Workshops & & & & \\
\hline IEA & Publications & $\begin{array}{l}\text { Summer schools } \\
\text { (IEA GHG) }\end{array}$ & $\begin{array}{l}\text { a/o roadmap and IEA } \\
\text { GHG studies }\end{array}$ & Workshops, publications & & \\
\hline OPEC & Workshops & Workshops & & & & \\
\hline GCCSI & $\begin{array}{l}\text { Meetings, } \\
\text { publications }\end{array}$ & $\begin{array}{l}\text { Workshops, } \\
\text { programmes }\end{array}$ & Publications & Publications & Uncertain & \\
\hline GEF & & & & & $\begin{array}{l}\text { Small scale, } \\
\text { bio-fuel }\end{array}$ & Small scale, bio-fuel \\
\hline IPCC & Through reports & $\begin{array}{l}\text { Through Special } \\
\text { Report }\end{array}$ & Special Report & Inventory guidelines & & \\
\hline UNEP & No activities & & & & & \\
\hline UNFCCC & In negotiations & & & $\begin{array}{l}\text { Uncertain (depends on } \\
\text { CDM) }\end{array}$ & & $\begin{array}{l}\text { Uncertain (depends } \\
\text { on CDM) }\end{array}$ \\
\hline $\begin{array}{l}\text { UNIDO } \\
\text { World Bank }\end{array}$ & Through roadmap & $\begin{array}{l}\text { Through roadmap } \\
\text { Programme under } \\
\text { development }\end{array}$ & Roadmap & & Specific countries & \\
\hline
\end{tabular}

and pooling of funding, neutral provision of information and arbitration activities. The debate on the prospects for CCS deployment implicates the barriers related to technological maturity, legislation, incentives and costs, public perception, the availability of geological storage potential information, and awareness in developing countries (IEA, 2009). However, gaps and barriers, such as public perception and high costs, are only partially covered by international organisations.

Information sharing, which Abbott and Snidal highlight as enabling state interaction, is an overarching theme. Abbott and Snidal, however, also emphasise the importance of the neutral provision of information. The IPCC had previously and credibly filled this role. The fossil fuel-oriented IEA now performs this function. Development of legislation is defined as the creation of procedures for the elaboration of norms. In the case of CCS, such development includes health and safety norms, permanence of storage, and arbitration of whether storage is credibly regulated.

\section{Explaining institutional fragmentation in the global governance of CCS}

The previous section demonstrated that different types of international organisations have increasingly addressed the topic of CCS. These entities include multilateral scientific organisations (such as the IPCC), UN agencies, the World Bank and international organisations outside the UN system. This section returns to the merits of the three theoretical perspectives in IR in accounting for the fragmented and diverse international landscape of CCS institutions. 
4.1. Realism: CCS organisations captured by the dominant interests of fossil fuel states

According to realist theory, international organisations ultimately reflect the interests of dominant states and, as a corollary, do not influence the behaviour or preferences of sovereign states. Hence, international organisations are not independent from state power; rather, such organisations further the interests of the most powerful states. These states are the major, industrialised, carbonemitter nations (US, Australia and Canada). Tjernshaugen (2008) estimates the "political commitment" to CCS by using data on investments in CCS research, development and demonstration in 2005 as a proxy. Although his results are limited to a single year and are comprised by a small number of countries and funding sources, one of his core findings is that commitment to CCS can be explained by the presence of an oil or gas industry in a country and, to a lesser degree, by coal reserves. These findings appear to confirm our initial intuition, i.e., that interest in CCS is linked to state interest in fossil fuel production (a position that Meadowcroft and Langhelle (2009a,b) also maintain). To what extent does this link also hold for international organisations?

Table 1 shows that major fossil fuel states dominate relevant international organisations and less institutionalised governance arrangements, such as public-private partnerships. The organisations where fossil fuel interests are strongly represented are also the strongest advocates of CCS and the most positive about the technology. As illustrated in Fig. 1, those organisations also tend to be more active in the field of CCS. In a realist perspective, states with energy systems dominated by fossil fuels have material and collective interests in developing, deploying and scaling up CCS technology. In the era of climate change mitigation, the mere availability of CCS is a means to legitimise the continued use of fossil fuel energy. Accordingly, coalitions of willing states or a hegemon, such as the US, establish international organisations that serve their material interests. Examples are the dominance of the United States in the CSLF and of Australia in the GCCSI. CSLF and the GCCSI are examples of organisations and public-private partnerships that industrialised countries specifically created to promote CCS technologies. The International Energy Forum (IEF) is geared towards the interests of oil-exporting states in realising CCS. In contrast, OPEC and IEA, which were founded in the 1970s to secure the interests of oil-producing and oil-consuming countries, have made CCS a high profile issue in the 1990s. OPEC countries, not least through vocal Saudi Arabia, are strong advocates of CCS technology in the UNFCCC negotiations.

It is also consistent with a realist account that the UN organisations and multilateral economic agencies remain neutral on CCS, even if they are more or less active in the CCS field. UN organisations with universal memberships appeal to the interests of smaller states. However, the UNFCCC negotiations are known for being slow and cumbersome due to the need to attain consensus among the 193 states. CCS has not gained a prominent role in the climate negotiations. After the IPCC pulled out of the discussions because its Special Report was finalised, and even though its Guidelines for Inventories had included CCS, it remained on the margins of CCS-related multilateral institutions and negotiation processes. Fossil fuel- and energy-related organisations saw an opportunity to fill the vacuum left by the UNFCCC. OPEC organised a number of roundtables. The G8 agreed on soft targets for CCS demonstrations and assigned the IEA to work with the CSLF to reach them. The International Energy Agency took on the responsibility of publishing regular overviews of CCS technology, economics and policy and has also given guidance to policymakers through its CCS Global Technology Roadmap. The CSLF continued to facilitate the exchange of documents and information between regulators and policymakers, with varying degrees of success. The
International Energy Forum organised workshops in developing countries on CCS. The World Bank, on the initiative of the Norwegian government, is setting up a capacity-building programme. The Global CCS Institute also has the goal of developing capacity and is looking for ways to add value beyond desktop studies. In addition, many bilateral and regional programmes now exist. International companies active in CCS are also struggling to understand in which processes they can best be involved to exert the most influence and extract the most out of demonstration projects.

Another assumption in realist theory is that international organisations lack teeth in terms of enforcement and regulatory powers because states are not willing give up core governance functions. Table 2 illustrates that most international organisations are engaged in soft governance functions, such as information sharing, studies, and workshops or capacity building in developing countries. When activities require greater investment of resources or coordination, such as funding for demonstrations and feasibility studies (which, in the case of CCS, often involve costly geological characterisations), there is less engagement. Although studies are quite common, coordinated R\&D is rare (although occasionally undertaken bilaterally between countries). We note that none of the organisations perform hard governance functions, such as regulation, finance and implementation. In a realistic perspective, this finding reflects the fact that states are reluctant to give up sovereignty by delegating core governance functions to international institutions with regard to energy production activities.

Section 3 clearly shows that CCS enthusiasts often are under the influence or representatives of energy, industry and fossil fuel interests, whereas in the climate negotiations, the most important drivers are moral imperatives, as well as development and green interests operating under the banner of sustainable development. The realist motivations embedded in the energy, industry and fossil fuel organisations conflict with the idealism of the environmental movement. Clearly, these positions are fundamentally different, leading to difficulties within climate negotiations in finding common ground and in collaborating on a common agenda on climate change and CCS. From a realist perspective, the institutional fragmentation of CCS in global politics and the slow progress on CCS in negotiations on CDM reflect business as usual in a world characterised by anarchy. States are not willing to delegate power to international organisations in areas that touch upon national security.

\subsection{Liberal institutionalism: CCS as part of a regime complex}

How would liberal institutionalism explain the fragmentation of international institutions around CCS? As outlined in the previous sections, liberal institutionalism is a rich tradition, ranging from regime theory to global governance theory to recent scholarly work on "regime complex". Given the well-established consensus that CCS qualifies as "an option in the portfolio of mitigation actions" among international organisations and states, it is noteworthy that the international institutional landscape on CCS is still fragmented and lacks any coherent, coordinated institutional response. While state-centric regime theory does not capture the non-hierarchical and hybrid nature of contemporary climate governance, the fragmentation of an issue area is not unfamiliar to liberal institutionalism. Raustiala and Victor (2004) describe a similar process for plant genetic resources, which consists of a "collective of partially overlapping and nonhierarchical regimes" leading to inconsistencies in framing and treatment. They identify the increasing value of plant genetic resources as a driving force for the diverging rules promulgated by different states and organisations striving to advance their interests. Similarly, the increasing political relevance of CCS in 
fossil fuel, energy and climate regimes may account for its emergence on the agendas of such international organisations as OPEC, IEA and the World Bank.

A core argument is that international institutions and regimes reflect a functional need among states for coordination in the process of jointly solving collective action problems. At one extreme are strongly integrated, comprehensive regulatory regimes that impose hierarchical rules; at the other end is a highly fragmented institution without a core and with weak linkages between different institutions and regime elements. Regime complexes, which are nested or semi-hierarchical regimes with identifiable cores and loosely coupled institutions, are located between these poles. Liberal institutionalism conceives of the evolving, CCS-related international institutions as part of an emergent "climate change regime complex". Keohane and Victor (2010, p. 2) have argued that regime complexes have advantages over integrated comprehensive regimes, which are unlikely to be successful because they are politically unrealistic. Efforts to craft a universally binding post-Kyoto treaty failed at the Copenhagen climate summit due to the fundamental conflicts of interest among the 193 states.

The diversity of international organisations depicted in Table 1 reflects the existence of a set of CCS institutions that form part of a larger climate-change regime complex. The UNFCCC does not represent a universal, comprehensive regulatory regime but rather an umbrella and forum where all the UN member states have an opportunity to deliberate. There are functional explanations for this regime complex. Keohane and Victor (2010, p. 14) argue from a functional standpoint that "the specific problems involved in regulating climate change are so varied that a single institutional response is exceptionally difficult to organize." We can apply this observation to international cooperation on CCS technologies that is associated with a diversity of interests, norms and beliefs. From a strategic perspective, a regime complex can offer flexibility for cooperation on climate abatement policies. Investment in technologies is central to reducing emissions, but efforts to include CCS in the CDM looked bleak in the UNFCCC negotiations until very recently. The only rationale for CCS is that it can generate greenhouse gas emission reductions. As a relatively narrow technology, CCS resonates with only a small portion of the negotiators and observers present at the Conferences of Parties. Although the topic of CCS engages those states that rely upon fossil fuel exports in the negotiations on climate change mitigation, it also alienates states whose primary objective is sustainable economic development and poverty alleviation, in which CCS is often either not well understood or seen mainly as a hindrance and a distraction. CCS, therefore, did not obtain as much traction as other technologies, such as renewable energy technologies that can serve, for example, development and energy access purposes. Because the incentives to coordinate technology investments on CCS in the UNFCCC are weak, smaller clubs of governments could seize opportunities to accelerate investments in low-carbon technology (Newell, 2010). Coalitions of states promoting CCS technologies outside the UNFCCC are evident in the information presented in Table 2. The Carbon Sequestration Leadership Forum and the Global CCS Institute were initiated by the US and Australia, respectively.

For traditional regime theorists, a comprehensive international regulatory regime of the UNFCCC is the natural home for CCS. However, alliances of developing countries in the UNFCCC have blocked the incorporation of CCS in the CDM. The climate change negotiations are much more multifaceted than CCS alone. The negotiations' dynamics involve a complex interaction among development and economic interests, adaptation and mitigation issues, and technologies and market mechanisms. The participation of business actors has also affected the dynamics of discussions over the issue of CCS in the UNFCCC context. CCS is an important reason for representatives from international fossil fuel companies to begin attending climate change negotiations. In the negotiations on CCS in the CDM (Coninck, 2008), those private sector actors advanced CCS to the top of the political agenda before many negotiators even grasped the basics of the technology. Moreover, some private sector actors made interventions in ways that experienced negotiators regarded as inappropriate, and some of the CCS advocates did not observe (unwritten) diplomatic rules. These developments may have contributed to the CCS community's greatest disappointment in the climate negotiations: the five-year long failure to reach a conclusion on allowing CCS to become part of CDM project activities.

\subsection{Constructivism: epistemic communities and the discursive shift to CCS as a legitimate climate mitigation technology}

A constructivist account argues that the complex international landscape of CCS institutions cannot solely be explained by powerbased and interest-based approaches. The role of scientific knowledge is critical in (re)defining the interests of key actors. Epistemic communities, which can be defined as networks of scientists and experts from national and multilateral agencies, have been instrumental in framing the role of CCS in a wider portfolio of climate change mitigation measures (Haas, 1990). As illustrated in Fig. 2, the IPCC was one of the pioneering organisations in systematically assessing the role of CCS in climate change abatement. Its 2005 Special Report represented an authoritative account of the scientific, socio-economic and technical dimensions of CCS technologies. Previously, debates on CCS were limited to communities of technical experts and tied to fossil fuel interests. The IPCC report was critical to the process of mainstreaming CCS in the climate change community and in the multilateral setting. The role of epistemic communities in the IPCC in building consensual and policy-relevant knowledge and reducing uncertainty for policymakers is evident because CCS emerged as a negotiation topic in deliberations on CDM. Beyond the institutional fragmentation of CCS in international governance arrangements, there has been a gradual normative shift towards wider acceptance of CCS as a low-carbon technology among governments, civil society and market actors, as exemplified by IEA (2009), and by the recent, more positive decision on CCS in the CDM (UNFCCC, 2010).

Social constructivism emphasises the critical role of competing discourses, storylines and arguments on CCS in the public debate and across different organisational and institutional settings. The institutional fragmentation of CCS issues apparent in Table 1 mirrors a discursive fragmentation of CCS in the global public debate. Meadowcroft and Langhelle (2009a,b, p. 269) identify dominant CCS storylines that have appeared in the public sphere, including those from enthusiastic proponents, reluctant proponents and critical sceptics. Most of the international organisations in Table 1 accept the dominant storyline that portrays CCS as a transitional technology that makes possible a low-carbon future in a world dominated by fossil fuels. Enthusiastic storylines embrace CCS as perhaps the most critical technology for achieving lowemission pathways and simultaneously express scepticism that renewable energy alternatives will constitute a substantial share of energy production within the timeframe necessary to achieve deep emission reductions. These storylines appear in the publications of such international organisations as CSLF, OPEC and the GCCSI. A discursive perspective also sheds light on discourses absent from the agenda of international organisations. Clearly, all of the CCS, fossil fuel and energy-focused international organisations surveyed in this paper lack critical and sceptical CCS storylines. Such storylines, often propagated by environmentally oriented non- 
governmental organisations, emphasise CCS as an "end-of-pipe" solution and a risky, late and expensive technology that will divert funds from renewables and energy efficiency.

\section{Conclusions}

This paper has mapped the plethora of international organisations and collaborative arrangements involving CCS technologies. Our aim is to provide three alternative theoretical accounts of the institutional fragmentation of CCS in global climate and energy politics. In the IR literature, realism, liberal institutionalism and constructivism provide three different explanations for the increased fragmentation of international collaboration on CCS. Known as power-based, interest-based and knowledge-based approaches, these theories provide different interpretations of the evolution of international organisations and furnish different answers to the question of whether international institutional fragmentation and diversity constitute a problem for effective international governance in solving collective action problems. One conclusion is that the realist, liberal institutionalist and constructivist explanations provide complementary interpretations of the fragmentation of the global politics of CCS.

Realist theories understand states as primary actors and argue that institutional fragmentation and the lack of coordination of CCS are "normal politics" because international institutions do not represent anything more than the sum of interests of states. In fact, realists argue, international institutions mirror the material interests of the most powerful states. A realist would not be surprised that CCS has moved gradually from the ambit of UN agencies to international organisations dominated by energy and fossil fuel interests. While the IPCC initially provided governance functions, such as the supply of information and legislation on CCS in national inventories, its role decreased in 2006. The IEA has gradually replaced IPCC as the key provider of information on CCS. The IEA is attuned to the interests of industrialised countries that are dependent on fossil fuels and possess large stakes in CCS technologies. The GCCSI also provides publicly available information. However, as an advocate for CCS, its legitimacy and independence are questionable.

Liberal institutionalism provides two interrelated interpretations of international cooperation on CCS. These are regime theory and recent work on "regime complexes". According to traditional regime theory, the large number of international organisations that have placed CCS on their agenda may have negative consequences for the technology. The international community's failure (or, at the very least, the failure of the group of countries that have an interest in CCS) to provide strong guidance and a favourable market environment for private sector investment is a consequence. However, the amount of global knowledge sharing and learning on different levels that would make possible sound and coordinated health and safety legislation, regulatory learning and a solid foundation of knowledge and experience in all countries remains at lower levels than desirable for the rapid deployment of CCS. A diversity of different organisations working on relatively low-effort activities, combined with the lack of centralisation (and, therefore, of clout on the part of any single international organisation), has led to a situation in which critical governance functions (joint R\&D, geological storage assessments, financing) have not been met. After the IPCC Special Report, the UN no longer acts as a node in the international coordination of CCS. Political influence is diffused over a large group of international organisations; no single organisation can be held responsible.

A realist account can explain this development. CCS only advantages governments with strong fossil fuel interests if climate mitigation is pursued. The primary interest of such states as Canada, Australia and the United States is not to deploy and roll out
CCS, but to delay aggressive climate abatement policies while symbolically promoting CCS research and capacity building. A fragmented regime complex on CCS without substantial and regulatory commitments to CCS suits the national interests of such states.

In contrast, recent literature on "regime complexes", which can be seen as a synthesis of realism and liberal institutionalism, does not regard as a failure the inability of the UNFCCC to play a central coordinating role in CCS activities. While climate change is CCS's raison d'être, for the UN to assume a leading position in the CCS field is to disregard the complex dynamics of the climate negotiations in which other international organisations outside the UN and "bottom-up initiatives" have taken on an active role. Since the problem structure in regulating climate change and CCS is so diverse, a single institutional response is difficult to organise. The consequence - institutional diversity and fragmentation - may even be positive because it promotes flexibility across issues and adaptability over time.

Finally, constructivism moves beyond material- and interestbased interpretations of the evolution of the institutionally fragmented architecture of global governance CCS governance. The IPCC Special Report of CCS in 2005 demonstrates the pivotal role of ideas, norms and scientific knowledge in transforming the preferences of the international climate change policy community.

\section{Acknowledgements}

We thank the MISTRA Foundation for supporting this international collaborative project. Our thanks also go to the co-editors of this special issue. Their feedback and suggestions have greatly improved the quality of this paper, as have the constructive comments from two anonymous referees. We also express our appreciation to the other researchers involved in this MISTRA CCS project. Over the course of several workshops, these researchers (particularly Mark Jaccard and Asbjørn Torvanger, who contributed to earlier versions of this paper) aided the development of this work. Finally, our thanks go to Tom Mikunda, who provided useful comments and edits.

\section{References}

Abbott, K., Snidal, J., 1998. Why states act through formal international organizations. The Journal of Conflict Resolution 42 (1), 3-32.

AGECC, 2010. Energy for a Sustainable Future. The Secretary General's Group on Energy and Climate Change (AGECC), New York, NY. , http://www.un.org/wcm/ webdav/site/climatechange/shared/Documents/AGECC\%20summary\%20 report\%5B1\%5D.pdf.

Aldy, J.E., Stavins, R.N. (Eds.), 2010. Post-Kyoto International Climate Policy. Implementing Architectures for Agreement. Cambridge University Press, Cambridge.

Bäckstrand, K., 2008. Accountability of networked climate governance: the rise of transnational climate partnerships. Global Environmental Politics 8 (3), 74-104.

Bernstein, S., Betsill, M., Hoffman, M., Paterson, M., 2010. A tale of two Copenhagens. Carbon markets and climate governance. Millennium: Journal of International Studies 39 (1), 161-173.

Biermann, F., 2006. Global governance and the environment. In: Betsill, M., Hochstetler, K., Stevis, D. (Eds.), International Environmental Politics. Palgrave MacMillan, New York, USA.

Biermann, F., Pattberg, P., van Asselt, H., Zelli, F., 2009. The fragmentation of global governance architectures. A framework for analysis. Global Environmental Politics 9 (4), 14-40.

Bodansky, D., 2010. The Art and Craft of International Environmental Law. Harvard University Press, Cambridge, MA/London, United Kingdom.

Bulkeley, H., Newell, P., 2010. Governing Climate Change. Routledge, New York/ London.

Coninck, H.de, Flach, T., Curnow, P., Richardsson, P., Anderson, J., Shackley, S., Sigurthorsson, G., Reiner, D., 2008. The acceptability of $\mathrm{CO}_{2}$ capture and storage (CCS) in Europe: an assessment of the key determining factors. Part 1. Scientific technical and economic dimensions. International Journal on Greenhouse Gas Control 3 (2), 333-343.

Coninck, H.de, 2008. Trojan horse or horn of plenty? Reflections on allowing CCS in the CDM. Energy Policy 36, 929-936. 
Coninck, H.C.de, Stephens, J.C.S., Metz, B., 2009. Global learning on carbon capture and storage: a call for strong international cooperation on CCS demonstration. Energy Policy 37, 2161-2165.

Falkner, R., 2005. American hegemony and the global environment. International Studies Review 7, 585-599.

Falkner, R., Stephens, H., Vogler, J., 2010. International climate policy after Copenhagen: Towards a ‘Building Blocks' approach. Approach Global Policy 1 (3), 252-317.

Finnemore, M., Sikkink, K., 1998. International norm dynamics and political change. International Organization 52, 887-917.

Ford, L., 2010. Transnational actors in global environmental politics. In: Kütting, G. (Ed.), Global Environmental Politics: Concepts, Theories and Case Studies. Routledge, London/New York.

Graaf, T.van de, Lesage, D., 2009. The international energy agency after 35 years: reform needs and institutional adaptability. Review of International Organization 4, 293-317.

Haas, P. 1990. Obtaining environmental protection through epistemic consensus. Millennium: Journal of International Studies 19 (3), 347-363.

IEA, 2004. Prospects for $\mathrm{CO}_{2}$ Capture and Storage. OECD/IEA, Paris, France.

IEA, 2008a. Energy Technology Perspectives. OECD/IEA, Paris, France.

IEA, 2008b. $\mathrm{CO}_{2}$ Capture and Storage, A Key Carbon Abatement Option. OECD/IEA Paris, France.

IEA, 2009. Technology Roadmap Carbon Capture and Storage. IEA, Paris, France.

IPCC, 2005. Special report on carbon dioxide capture and storage. In: Metz, B. Davidson, O., Coninck, H.C.de, Loos, M., Meyer, L.J. (Eds.), Prepared by Working Group III of the Intergovernmental Panel on Climate Change. Cambridge University Press, Cambridge, United Kingdom/New York, NY, USA, 442 pp.

IPCC, 2007a. Climate Change Science. Working Group I's contribution to the Fourth Assessment Report of the Intergovernmental Panel on Climate Change. Cambridge University Press, Cambridge, UK.

IPCC, 2007b. Climate Change Mitigation. In: Metz, B., Davidson, O., Bosch, P., Dave, R., Meyer, L. (Eds.), Contribution of Working Group III to the Fourth Assessment Report of the Intergovernmental Panel on Climate Change. Cambridge University Press, Cambridge, UK, p. 851.

Karlsson-Vinkhuyzen, S., 2010. The United Nations and global energy governance. Past, present and future choices. Global Change, Peace and Security 22 (2), 175-195.

Keohane, R., 1984. After Hegemony. Cooperation and Discord in the World Political Economy. Princeton University Press, Princeton, USA.

Keohane, R., 1988. International institutions: two approaches. International Studies Quarterly 32, 379-386.
Keohane, R., Victor, D., 2010. The regime complex for climate change. The Harvard Project on International Climate Agreements. Discussion Paper 10-33, Harvard Kennedy School of Government, Cambridge, MA.

Krasner, S.D., 1983. International Regimes. Cornell University Press, Ithaca, NY.

Litfin, K., 1992. Ozone Discourses. Science and Politics in Global Environmental Cooperation. Colombia University Press, New York.

Marchetti, C., 1977. On geo-engineering and the $\mathrm{CO}_{2}$ problem. Climate Change 1 , 59-68.

Meadowcroft, J., Langhelle, O. (Eds.), 2009a. Caching the Carbon: The Politics and Policy of Carbon Capture and Storage. Edward Elgar, Cheltenham, UK.

Meadowcroft, J., Langhelle, O., 2009b. The politics and policy of CCS. The uncertain road ahead. In: Meadowcroft, J., Langhelle, O. (Eds.), Caching the Carbon: The Politics and Policy of Carbon Capture and Storage. Edward Elgar, Cheltenham, UK.

Newell, R., 2010. International climate technology strategies. In: Aldy, J.E., Stavins, R.N. (Eds.), Post-Kyoto International Climate Policy. Implementing Architectures for Agreement. Cambridge University Press, Cambridge.

Raustiala, K., Victor, D., 2004. The regime complex for plant genetic resources. International Organization 58, 277-309.

Rosenau, J., 2007. Governing the ungovernable. The challenge of global disaggregation of global authority. Regulation and Governance 1, 88-97.

Shackley, S., Reiner, D., Upham, P., Coninck, H.de, Sigurthorsson, G., Anderson, J., 2008. The acceptability of $\mathrm{CO}_{2}$ capture and storage (CCS) in Europe: an assessment of the key determining factors. Part 2. The social acceptability of CCS and the wider impacts and repercussions of its implementation. International Journal on Greenhouse Gas Control 3 (2), 344-356.

Slaughter, A.M., 2004. A New World Order. Princeton University Press, Princeton.

Tjernshaugen, A., 2008. Political commitment to $\mathrm{CO}_{2}$ capture and storage: evidence from government RD\&D budgets. Mitigation and Adaption Strategies for Global Change 13, 1-21.

UNFCCC, 2010. Decision/CMP.6: Carbon dioxide capture and storage in geological formations as clean development mechanism project activities. , Available onhttp://unfccc.int/files/meetings/cop_16/application/pdf/ cop16 cmp_ccs.pdf.

Vogler, J., 2010. International Relations theory and the environment. In: Kütting, G. (Ed.), Global Environmental Politics: Concepts, Theories and Case Studies. Routledge, London/New York.

Young, O. (Ed.), 1997. Global Governance. Drawing Insights from the Environmental Experience. MIT Press, Cambridge, MA 